\title{
APLIKASI PENDUKUNG KEPUTUSAN ANALISA PENILAIAN GURU BERPRESTASI MENGGUNAKAN METODE SIMPLE ADDITIVE WEIGHTING (SAW)
}

\author{
*Siti Aisyah, Desi Lestari \\ Program Studi Sistem Informasi \\ Fakultas Teknologi dan Ilmu Komputer Universitas Prima Indonesia \\ E-mail : *sitiaisyah@unprimdn.ac.id
}

\begin{abstract}
ABSTRAK- Setiap instansi baik itu dibidang apapun memiliki konsep atau cara dalam memberikan penilaian terhadap tim pekerja mereka. Guru merupakan salah satu ujung tombak dalam keberhasilan proses pembelajaran. Cara mengajar yang baik dapat memberikan suasana yang nyaman bagi anak didik dalam melaksanakan pembelajaran. Untuk memberikan penghargaan dan menambah semangat serta kreativitas para guru dalam mengajar perlu dilakukan sebuah penilaian. Penilaian tersebut nantinya untuk memberikan penghargaan kepada guru yang memiliki nilai tertinggi sebagai guru terbaik. Berdasarkan permasalahan tersebut maka penelitian ini bertujuan untuk merancang suatu sistem pendukung keputusan terhadap penilaian. Metode yang digunakan adalah Simple Additive Weighting (SAW). Terdapat lima kriteria yang penulis gunakan yaitu Kedisiplinan, Prestasi, Tanggung Jawab, Inisiatif dan Presensi. Penelitian dilakukan dengan mencari nilai bobot untuk setiap kriteria, kemudian dilakukan proses perankingan yang menentukan guru berprestasi pada studi kasus tersebut.
\end{abstract}

Kata kunci : Guru, Berprestasi, SAW.

\section{PENDAHULUAN}

Saat ini teknologi informasi telah berkembang pesat mengikuti arus globalisasi. Perkembangan teknologi informasi mendorong terciptanya penggunaan teknologi dalam berbagai bidang kehidupan manusia. Salah satu penerapan teknologi informasi adalah dalam dunia pendidikan. Guru merupakan sumber daya manusia yang penting dalam di dalam dunia pendidikan. Jika kinerja guru dapat dikelola dengan baik, maka diharapkan sekolah dapat menjalankan semua proses kegiatan belajar mengajar dengan baik. Saat ini penilaian kinerja guru masih dilakukan banyak dilakukan secara konvensional. Yang menjadi masalah adalah proses konvensional membutuhkan waktu yang lama dan penilaian kurang objektif.

Guru merupakan satu kesatuan dengan sekolah. Guru berprestasi dapat berpengaruh pada kemajuan sekolah, oleh sebab itu melakukan penilaian terhadap guru adalah hal yang penting bagi setiap sekolah. Sekolah yang berkualitas pasti memiliki guru yang berprestasi. Untuk melakukan penilaian tehadap prestasi guru, setiap sekolah akan memiiki standar penilaian masing masing.

Sistem Pendukung Keputusan (SPK) salah satu bidang ilmu teknologi yang dapat digunakan sebagai sarana pendukung dalam sebuah organisasi untuk memperoleh sebuah keputuan. Penggunaan SPK biasanya dilakukan dengan memadukan sebuah satu atau beberapa metode. Penelitian yang menggunakan WASPAS (Weighted Aggregated Sum Product Assessment) dapat membantu pengambil keputusan dalam memutuskan satu atau lebih dari beberapa alternatif yang harus diambil sebagai bahan pertimbangan. Banyak peneliti terdahulu yang telah menggunakan sistem ini untuk mengatasi permasalahan-permasalahan yang ada pada penelitian mereka dengan menerapkan metode seperti Analytical Hierarchy Process( AHP) [3]-[4], Weighted Product (WP)

\section{METODE PENELITIAN}

Penelitian ini menggunakan sistem pendukung keputusan dengan metode SAW. Dimana kriteria yang digunakan sebanyak 5 yaitu : Kedisiplinan, prestasi, tanggung jawab, inisiatif, presensi.

Pada penelitian ini data yang diolah sebanyak 30 guru dan sampel yang dipakai sebagai bahan pengujian sebanyak 4 sampel.

\section{HASIL DAN PEMBAHASAN}

\subsection{Perancangan Sistem}

Pada bagian ini akan dijelaskan langkahlangkah atau tahapan dari penilaian guru terbaik dengan menggunakan metode SAW dengan melakukan penghitungan secara manual. Adapun tahapan yang dimaksud sebagai berikut:. 


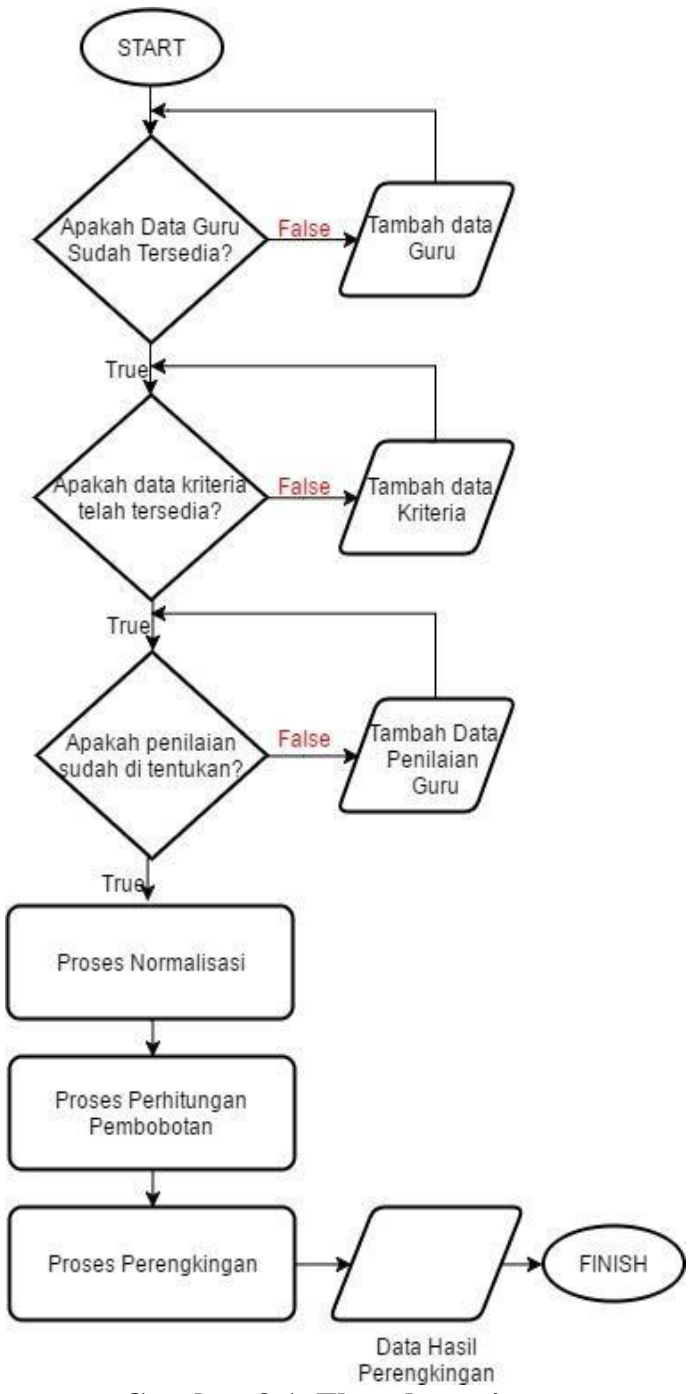

Gambar 3.1. Flowchart sistem

\subsection{Proses Penghitungan}

Pada bagian ini akan dijelaskan langkahlangkah atau tahapan dari penilaian guru terbaik dengan menggunakan metode SAW dengan melakukan penghitungan secara manual. Adapun tahapan yang dimaksud sebagai berikut:

1. Menentukan data sampel

Pada penelitian ini hanya sebanyak 4 nama guru yang akan dijadikan sebagai data sampel

Gambar 3.1. Data sampel guru

\begin{tabular}{|l|l|l|}
\hline No. & Kode & \multicolumn{1}{|c|}{ Nama Guru } \\
\hline 1 & G1 & Ms Yunda \\
\hline 2 & G2 & Sr Akhyar \\
\hline 3 & G3 & Ms Yohan \\
\hline 4 & G4 & Sr Dinardo \\
\hline
\end{tabular}

2. Menentukan kriteria dan bobot

Selain data sampel, kriteria dan bobot merupakan bagian yang terpenting dalam metode SAW. Hal ini dikarenakan kriteria dan bobot digunakan untuk melakukan penghitungan terhadap data sampel.
Tabel 3.2. Bobot dan Kriteria

\begin{tabular}{|c|c|c|}
\hline No & Nama Kriteria & Bobot \\
\hline C1 & Kedisiplinan & 0,2 \\
\hline C2 & Prestasi & 0,15 \\
\hline C3 & Tanggung Jawab & 0,3 \\
\hline C4 & Inisiatif & 0,25 \\
\hline C5 & Presensi & 0,1 \\
\hline
\end{tabular}

3. Pemberian nilai kriteria guru

Pada proses pengambilan nilai kriteria, nilai yang diambil adalah nilai tertinggi dari penilaian yang dilakukan sebanyak 6 kali disetiap kriteria penilaian. Nilai tertinggi yang diambil pada kriteria penilaian dapat dilihat pada Tabel 3.3

Tabel 3.3 Nilai kriteria guru

\begin{tabular}{|c|c|c|c|c|c|}
\hline \multirow{2}{*}{$\begin{array}{c}\text { Kode } \\
\text { Guru }\end{array}$} & \multicolumn{5}{|c|}{ Kriteria } \\
\cline { 2 - 6 } & C1 & C2 & C3 & C4 & C5 \\
\hline G1 & 90 & 90 & 97 & 95 & 97 \\
\hline G2 & 99 & 99 & 99 & 90 & 99 \\
\hline G3 & 99 & 99 & 99 & 99 & 90 \\
\hline G4 & 98 & 95 & 98 & 95 & 90 \\
\hline
\end{tabular}

4. Penghitungan normalisasi

Setelah didapatkan nilai untuk masing-masing kriteria dari setiap alternatif, maka selanjutnya adalah menghitung nilai normalisasi dengan menggunakan rumus pada gambar 3.2. dan didaptkan hasil pada tabel 3.4.

Tabel 3.4. Hasil normalisasi

\begin{tabular}{|r|c|c|c|c|c|}
\hline $\begin{array}{r}\text { Kode } \\
\text { Guru }\end{array}$ & C1 & C2 & C3 & C4 & C5 \\
\hline G1 & 0.909 & 0.909 & 0.979 & 0.956 & 0.979 \\
\hline G2 & 1 & 1 & 1 & 0.909 & 1 \\
\hline G3 & 1 & 1 & 1 & 1 & 0.909 \\
\hline G4 & 0.989 & 0.959 & 0.989 & 0.959 & 0.909 \\
\hline
\end{tabular}

5. Penghitunan pembobotan

Hasil normalisasi yang didapat akan dikalikan dengan nilai pembobotan pada setiap kriteria penilaian sesuai dengan rumus dibawah ini hasil dari perhitungan dapat dilihat pada tabel 3.5.

Tabel 3.5. Hasil perhitungan pembobotan

\begin{tabular}{|c|c|c|c|c|c|c|}
\hline $\begin{array}{r}\text { Kode } \\
\text { Guru }\end{array}$ & C1 & C2 & C3 & C4 & C5 & Hasil \\
\hline G1 & 0.181 & 0.136 & 0.293 & 0.239 & 0.097 & 0.95 \\
\hline G2 & 0.2 & 0.15 & 0.3 & 0.227 & 0.1 & 0.977 \\
\hline G3 & 0.2 & 0.15 & 0.3 & 0.25 & 0.090 & 0.990 \\
\hline G4 & 0.197 & 0.143 & 0.296 & 0.239 & 0.090 & 0.969 \\
\hline
\end{tabular}


Setalah dilakukan penghitungan perangkinan maka Tahap terakhir adalah untuk mengurutkan ranking guru berdasarkan nilai hasil yang didapat pada pembobotan. Ranking guru dapat dilihat pada table 3.6

Tabel 3.6. Perankingan

\begin{tabular}{|c|c|c|}
\hline Rangking & Nama guru & Nilai Akhir \\
\hline 1 & Ms Yohan & 0.99091 \\
\hline 2 & Sr Akhyar & 0.97727 \\
\hline 3 & Sr Dinardo & 0.96970 \\
\hline 4 & Ms Yunda & 0.95 \\
\hline
\end{tabular}

\subsection{Perancangan Antar Muka}

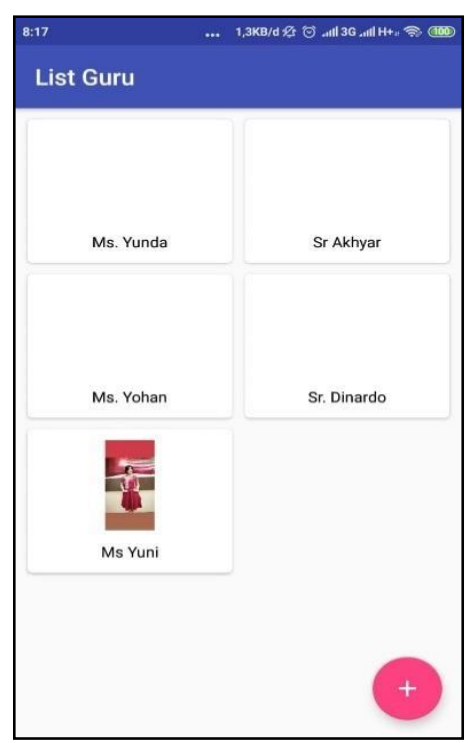

Gambar 3.3.a. Form list guru

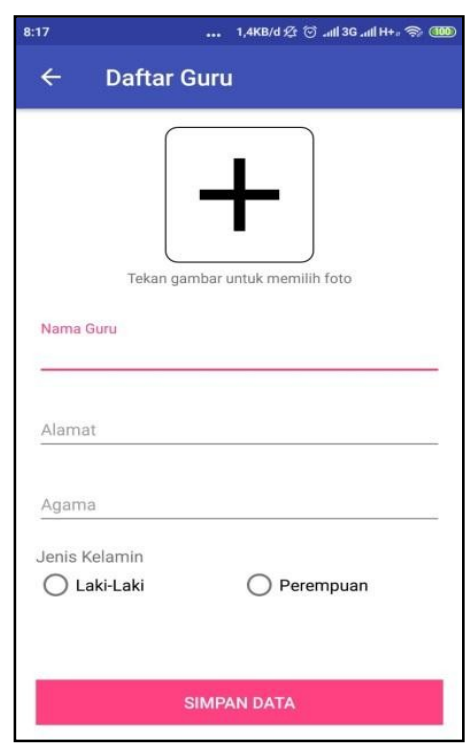

Gambar 3.3.b. Form tambah data pada gambar 3.3.a. merupakan form yang berfungsi untuk menampilkan list data guru, sedangkan pada gambar 3.3.b. berfunsi utnuk menambahkan data guru kedalam sistem.

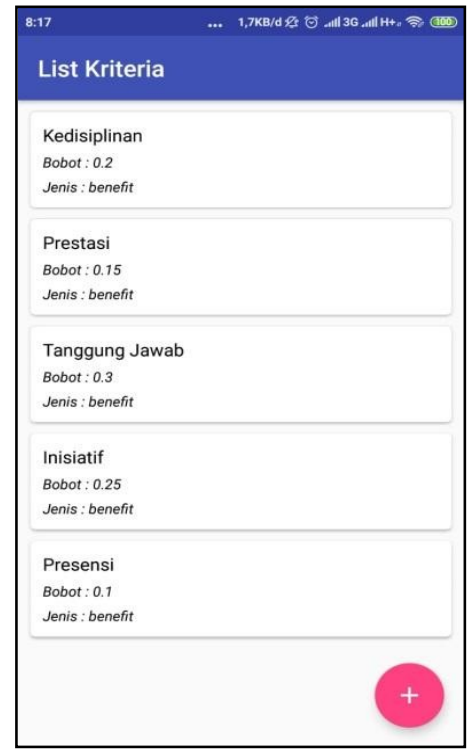

Gambar 3.4.a. Form list kriteria

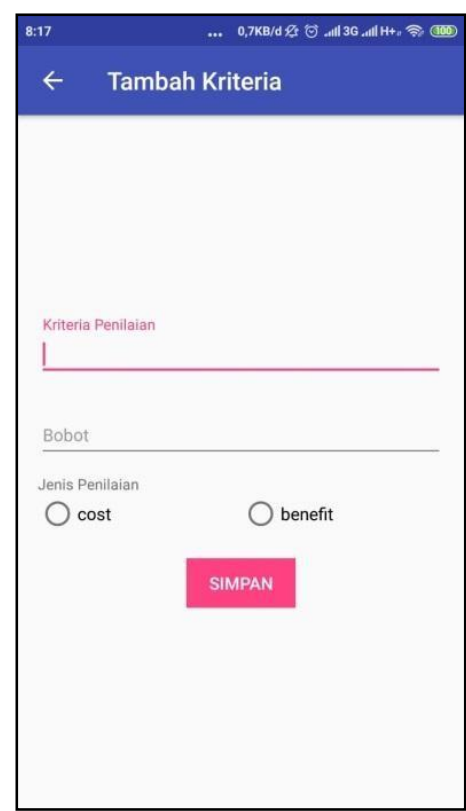

Gambar 3.4.b. Form tambah kriteria

Gambar 3.4.a. berfungsi untuk menampilkan data kriteria yang digunakan dalam sistem untuk emperoses data guru terbaik. Sedangkan pada gambar 3.4.b. berfungsi untuk mengedit, menambahkan dan sekaligus menghapus data kriteria. 


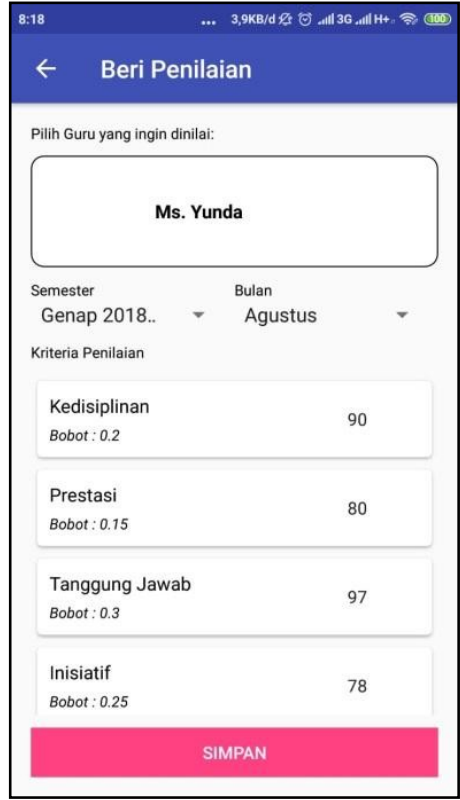

Gambar 3.5.a. Form proses penilaian

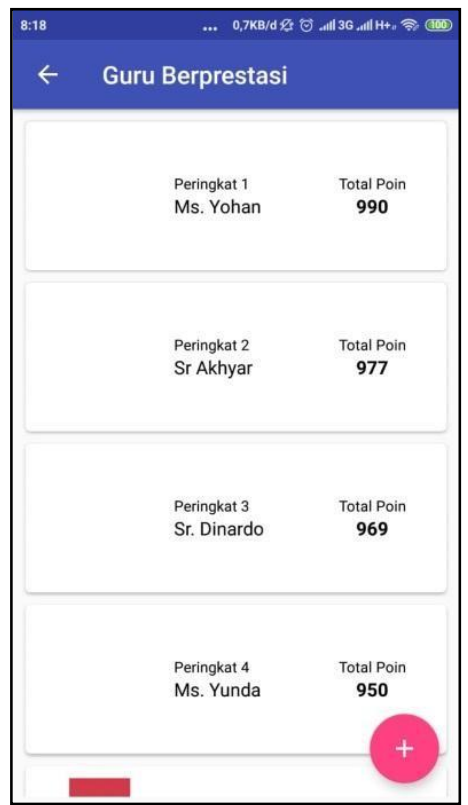

Gambar 3.5.b. Form hasil penilaian

\section{PENUTUP}

\subsection{Kesimpulan}

1. Sistem pendukung keputusan dapat dimanfaatkan sebagai sarana pendukung dalam pengambilan keputusan bagi para pimpinan terhadap guru.

2. Dengan menerapkan sistem komputerisasi dalam pemilihan guru berprestasi, maka proses pengolahan data lebih cepat dan tepat serta mengurangi kesalahan dalam perhitungannilai.

\subsection{Saran}

1. Objek penelitian tidak hanya dapat dilakukan di satu sekolah, tetapi juga dapat dibuat suatu perbandingan antara satu sekolah dengan sekolah yang lainnya.

2. Kriteria penilaian dapat dikembangkan lagi untuk mendapat indeks penilaian yang lebih variatif dan berimbang.

3. Penambahan beberapa fitur lagi didalam aplikasi.

\section{DAFTAR PUSTAKA}

[1] Safrizal Barus, Vera Meikana Sitorus, Darmawan Napitupulu, Mesran, Suriyanti. "Sistem Pendukung Keputusan Pengangkatan Guru Tetap Menerapkan Metode Weight Aggregated Sum Product Assesment (WASPAS). Media Informatika Budidharma Vol. 2 No. 2, pp 15 - 25, 2018.

[2] AnjarWanto, Hamongan Damanik., "AnalisisPerancangan Sistem Pendukung Keputusan Terhadap Seleksi Penerimaan Beasiswa BBM (Bantuan Belajar Mahasiswa) Pada Perguruan Tinggi menggunakan Metode Simple Additive Weighting. Prosiding seminar nasional Rekayasa” Vol. 2. ISSN : 2407- 735, 2015.

[3] Agus Perdana Windarto,. Penilaian Prestasi Karyawan PTPN III Pematang Siantar dengan Metode Simple Additive Weighting. Jurnal Riset SistemInformasi dan Teknik Informatika Vol.2 No.1. ISSN2527-5771, e-ISSN :25497839.

[4] Abdillah, Rahman, "Implementasi Fuzzy Simple Additive Weghting (SAW) SebagaiPendukungKeputusanPadaBeasiswaPe nelitian", Vol.2No. 1, p-ISSN: 2527 - 9661, eISSN : $2549-2837,2017$.

[5] Atika, Fara, "Sistem Pendukung Keputusan Pemilihan Guru Berprestasi Di Kecamatan Kradenan Kabupaten Grobogan Menggunakan Metode Simple Additive Weighting. Universitas Muhammadiyah Surakarta" :Surakarta, 2017.

[6] Chintyari, Yananda Eka., Titin Prihatin, "Implementasi Metode Simple Additive Weighting Untuk Pemilihan Guru Berprestasi Pada SMP Islam Pondok Duta", Vol. 3. No. 2 E-ISSN : 2527-4864.Jakarta, 2018.

[7] Frieyadie, "Penerapan Metode Simple Additive Weight (Saw) Dalam Sistem Pendukung Keputusan Promosi Kenaikan Jabatan", Vol.XII, No. 1.Jakarta, 2016.

[8] Gumelar, Agum, "Sistem Pendukung Keputusan Pemilihan Handphone dengan Metode Simple Additive Weighting (SAW). Universitas Muhammadiyah Surakarta", Surakarta, 2017.

[9] Hariyanto, Siti Khotimah, "Sistem Pendukung Keputusan PemilihanSupplierTerbaik Telur 
JUSIKOM PRIMA (Junal Sistem Informasi Ilmu Komputer Prima)

Vol. 3 No. 2, Februari 2020

BermerkMenggunakan Metode SAW StudiKasus PT. GIANT PONDOK KOPI", Vol.3 No. 2, ISSN :2503-1945. Banten, 2018.

[10] Masri, Mahrizal, "Penentuan Karyawan Terbaik Dengan Metode Simple Additive Weighting (PDAM Tirta Silaupiasa)", Journal of Electrical Technology Vol. 1, No. 1,ISSN : 2502 - 3624.Medan, 2016.

[11] Pradipta, Aldi Yudha, Anita Diana, "Sistem Penunjang Keputusan Pemilihan Supplier pada Apotek dengan Metode AHP dan SAW (Studi Kasus Apotek XYZ)" Prosiding SISFOTEK, ISSN : 2597 - 3584, Jakarta, 2017.

[12] Ruzain, Dian Hasabi, "Implementasi Metode Saw (Simple Additive Weighting) Pada Sistem Pendukung Keputusan Rekomendasi Pemilihan Sma Swasta Di Bandar Lampung Berbasis Web”, Universitas Lampung :Lampung, 2017.

[13] Setiadi, Ahmad, Yunita, Anisa Ratna Ningsih, , "PenerapanMetode Simple Additive Weighting (SAW) Untuk Pemilihan Siswa Terbaik". Jurnal SISFOKOM, Vol.7, No.2.Jakarta, 2018.

[14] Sihombing, Rotua, Agus Perdana, Dedy Hartama, Solikhun, "Sistem Pendukung Keputusan Pemilihan Guru Terbaik Pada SMK Maria Goretti Pematangsiantar Menggunakan Metode Simple Additive Weighting (SAW). JURASIK (Jurnal Riset Sistem Informasi \& Teknik Informatika)", Vol. 1, No. 1, ISSN 2527-5771.Pematangsiantar, 2016.

[15] Suryati, Zuraidah Jauhari, "Pemilihan Guru Berprestasi Menggunakan DSS (Decision Support System) Dengan Metode FMADM (Fuzzy Multiple Attribute Decission Making) Dan SAW (Simple Additive Weighting)", Jurnal IlmiahFifoVol.X,No.1.P-ISSN:2085-4315,EISSN:2502-8332.Palembang, 2018. 